Elsevier

\title{
Synergism of mutant frequencies in the mouse lymphoma cell mutagenicity assay by binary mixtures of methyl methanesulfonate and ethyl methanesulfonate
}

\author{
K.S. Tarlo ${ }^{1}$, Michael Boehnke ${ }^{2}$ and Bruce Chin ${ }^{1}$ \\ 'Department of Environmental and Industrial Health, School of Public Health, The University of Michigan, Ann Arbor, MI 48109 \\ and ${ }^{2}$ Department of Biostatistics, School of Public Health, The University of Michigan, Ann Arbor, MI 48109 (U.S.A.)
}

(Received 24 September 1987)

(Revision received 24 February 1988)

(Accepted 26 April 1988)

Keywords: Mutant frequencies, synergism; Mouse lymphoma cell mutagenicity assay; Methyl methanesulphonate; Ethyl methanesulphonate

\section{Summary}

The effect of mixed mutagen exposures on the rate and type of induced mutants was studied in the $\mathrm{L} 5178 \mathrm{Y} / \mathrm{TK}^{+/-} \rightarrow \mathrm{TK}^{-/-}$mouse lymphoma cell mutagenicity assay. In this assay, exposure to ethyl methanesulfonate (EMS) results in more mutants that form large colonies than small colonies. Exposure to methyl methanesulfonate (MMS) results in more mutants that form small colonies than large colonies. Other reports in the literature suggest that large colony $\mathrm{TK}^{-/-}$mutants appear to result from small-scale, perhaps single-gene mutations, and that small-colony $\mathrm{TK}^{-1-}$ mutants appear to be associated with chromosomal mutations. Treating cells for $4 \mathrm{~h}$ with simple, 2-component mixtures containing $6.45 \mu \mathrm{g} / \mathrm{ml}$ MMS and either 261, 392, 560 or $712 \mu \mathrm{g} / \mathrm{ml}$ EMS resulted in synergism of mutants at each mixture level. The frequencies of total mutants were synergized $12,20,35$ and $72 \%$, respectively, in mixed exposures with graded doses of EMS, above the sums of the mixture components. Small colony mutants were synergized to a greater extent than large colony mutants. The frequencies of small colony mutants in mixed exposures were increased $31,54,73$ and $123 \%$, respectively, while the frequencies of large colony mutants were increased $-7,-6,11$ and $39 \%$. Statistical analyses provide strong evidence of synergism (within the limits of the assay) for total and small-colony mutants at all doses of EMS tested, and for large-colony mutants above $400 \mu \mathrm{g} / \mathrm{ml}$ EMS. Similar magnitudes of synergism resulted when other constant levels of MMS (4.30 or $8.60 \mu \mathrm{g} / \mathrm{ml}$ ) were mixed with the same graded doses of EMS. The degree of synergism was dependent on EMS concentration but not on MMS concentration.

Most mutagenicity studies evaluate the mutagenicity of single agents rather than mixtures of agents, a situation more representative of exposures in nature. Valuable information has come

Correspondence: Dr. K.S. Tarlo, Department of Environmental and Industrial Health, School of Public Health, The University of Michigan, Ann Arbor, MI 48109 (U.S.A.). from studies with single agents, but increasing interest in identifying and assessing environmental hazards points to the need for more information on mixed exposures. A review of mixed exposures and chemical interactions relative to mutagenicity has been published by Tennant et al. (1987). Synergism of mutants has been demonstrated in vitro and in vivo. Using the Ames assay, synergism results with mixtures of benzo[ $a]$ pyrene and 
benzo[ $e]$ pyrene (Hass et al., 1981), with mixtures of propyl gallate and $N$-hydroxy-2-acetylaminofluorene (Rosin, 1981), and from our laboratory, with mixtures of aflatoxin $B_{1}$ and butylated hydroxytoluene (Shelef and Chin, 1980). Synergistic effects have also been observed in mammalian cells (V79) with 1,3-bis(2-chloroethyl)-1nitrosourea (BCNU) and streptozocin (Harbach et al., 1982). Using the micronucleus assay, Watanabe et al. (1982) showed that $\mathrm{Cd}^{2+}$ enhanced the mutagenicity of dimethylnitrosamine in mice.

The $\mathrm{L} 5178 \mathrm{Y} / \mathrm{TK}^{+/-} \rightarrow \mathrm{TK}^{-/-}$mouse lymphoma cell mutagenicity assay, as standardized by Turner et al. (1984), was used in the present study because it permits the recovery of two classes of thymidine kinase (TK) deficient mutants. By using EMS and MMS, each of which induces predominantly one class of mutant, L5178Y $/ \mathrm{TK}^{+/-}$cells afford a unique way of studying the genotoxic effects resulting from the interaction of these two mutagens. Clive et al. (1979) reported that $\mathrm{TK}^{-/-}$mutant colonies in soft agar have a bimodal distribution for size. Mutants form large and small colonies, depending on the type of genetic damage (Clive and MooreBrown, 1979; Moore-Brown and Clive, 1979; Clive et al., 1980; Clive, 1983; Moore et al., 1985a). Large colonies indicate small-scale, perhaps intragenic (single-gene), damage and small colonies represent larger incursions on the genome, perhaps in the form of intergenic (chromosomal) damage. Some doubt concerning the origin of small-colony mutants has been raised by Amacher and Paillet (1981), who suggested that small colonies can result from trifluorothymidine (TFT) selection or delayed toxicity. Their skepticism was recently proven to be unwarranted because: (1) Oberly et al. (1986) showed that induced and spontaneously formed small-colony mutants truly lack TK enzyme activity, and (2) additional cytogenetic data established that most small-colony mutants originate from cells that possess at least one chromosomal aberration in chromosome 11 (Hozier et al., 1981, 1983, 1985; Moore et al., 1985b; Blazak et al., 1986), which contains the mouse $t k$ gene (Kozak and Ruddle, 1977).

In this publication, we apply binary mixtures of MMS and EMS to the mouse lymphoma cell mutagenicity assay and show that these mixtures synergize the formation of mutant colonies. We introduce the term \% change, as a measure of the magnitude of synergism relative to the mutant frequencies in separate exposures. Mixtures of MMS and EMS are synergistic in accordance with the definition proposed by the United Nations Scientific Committee (1982): the number of mutants obtained with mixtures of MMS and EMS exceeds the sum of the mutants obtained with separate exposures to MMS and EMS. At the doses tested, synergism was dependent on EMS concentration but not MMS concentration. Surprisingly, synergism was higher among small colony mutants - the predominant type produced by MMS - than among large-colony mutants, which are the predominant type induced by EMS.

\section{Materials and methods}

\section{Cell culture}

Mouse lymphoma L5178Y $/ \mathrm{TK}^{+/-}-3.7 .2 \mathrm{C}$ cells were obtained through the generosity of Dr. Donald Clive, Burroughs Wellcome Co., Research Triangle Park, NC. They were maintained in suspension culture in Fischer's medium (Gibco, Grand Island, NY), supplemented with $10 \%$ horse serum, $0.22 \mu \mathrm{g} / \mathrm{ml}$ sodium pyruvate, and 1.0 $\mathrm{mg} / \mathrm{ml}$ Pluronic F68 (BASF Corp., Wyandotte, MI). Cultures were incubated at $37^{\circ} \mathrm{C}$ on a combination incubator-shaker (125 rpm) and cleansed weekly to kill spontaneously formed $\mathrm{TK}^{-/-}$ mutants.

\section{Mutagens}

MMS (Eastman Kodak Co.) and EMS (Eastman Kodak Co.) were purchased from Sigma Chemical Co., St. Louis, MO. MMS was dissolved in phosphate-buffered saline (PBS). EMS was dissolved in dimethyl sulfoxide (DMSO) and diluted with PBS. Each culture flask (treated and solvent controls) contained the same amount of DMSO $(0.1 \%)$ and PBS. Both mutagens were prepared fresh and sterilized by filtration.

\section{Mutation assay}

The L5178Y $/ \mathrm{TK}^{+/-} \rightarrow \mathrm{TK}^{-1-}$ mouse lymphoma cell mutagenicity assay was conducted in conformance with the protocol of Turner et al. (1984), with a 4-h exposure to mutagen followed by $48 \mathrm{~h}$ for expression of mutations. The selection medium for $\mathrm{TK}^{-/-}$mutants contained $1.0 \mu \mathrm{g} / \mathrm{ml}$ trifluoro- 
thymidine (Sigma Chemical Co.), 0.37\% Noble agar (Difco, Detroit, MI), and 20\% horse serum in Fischer's medium. $\mathrm{TK}^{-/-}$mutants were selected after incubation for $14 \mathrm{~d}$ in the presence of TFT under $5 \% \mathrm{CO}_{2}$ in air at $37^{\circ} \mathrm{C}$. Mutant colonies were counted by eye with the aid of a magnifying colony counter. Small and large colonies in soft agar were distinguished by size. The criteria for scoring a small colony were that the colony be round, intact, and in the range of $0.15-0.6 \mathrm{~mm}$ in diameter. Typical colony sizes were determined by a magnifying lens that contained a sizing grid. Most small colonies were approximately $0.25 \mathrm{~mm}$ in diameter. Large colonies were approximately 3-4 times the diameter of small colonies. A large colony, likewise, had to be round, intact, and in the range of $0.60-1.0 \mathrm{~mm}$ in diameter. Most large colonies were approximately $0.75 \mathrm{~mm}$ in diameter.

\section{Statistical analysis of mixtures}

Induced mutant frequencies (IMFs) were calculated as the number of induced mutants $/ 10^{6}$ survivors for total mutants, small-colony mutants, and large colony mutants. IMFs were used to calculate \% change:

$\frac{\mathrm{IMF}_{\mathrm{A}+\mathrm{B}}-\left(\mathrm{IMF}_{\mathrm{A}}+\mathrm{IMF}_{\mathrm{B}}\right)}{\mathrm{IMF}_{\mathrm{A}}+\mathrm{IMF}_{\mathrm{B}}} \times 100=\%$ change

where A and B are components of mixtures. Positive $\%$ change indicates synergism, zero $\%$ change indicates addition, and negative $\%$ change indicates antagonism.

Synergism of total, small, and large colony mutants was analyzed by weighted least squares regression analysis (Neter et al., 1985). A weighted approach was selected because the observed variability in \% change increased with EMS dose. Inverse sample variances were used as the weights for regression analysis.

\section{Results}

Mutant colonies were synergized when mouse lymphoma cells were exposed to binary mixtures of MMS and EMS. Within an experiment, cells were exposed to a constant concentration of MMS (either $4.30,6.45$ or $8.60 \mu \mathrm{g} / \mathrm{ml}$ ) and graded concentrations of EMS (261, 392, 560 and $712 \mu \mathrm{g} / \mathrm{ml}$ ).
Tables 1 and 2 show the results of a typical, constant MMS:gradeed EMS mixed exposure experiment, in this case to $6.45 \mu \mathrm{g} / \mathrm{ml} \mathrm{MMS} \mathrm{+} \mathrm{261,}$ 392,560 or $712 \mu \mathrm{g} / \mathrm{ml}$ EMS. Table 1 lists the data (colony counts, survival and mutant frequencies) used for the analysis of synergism, which is presented in Table 2. The dose of MMS was mildly toxic $(83 \%$ relative total growth and mutagenic (IMF $=386$; spontaneous frequency $\left(f_{\mathrm{s}}=55\right)$. In our laboratory, dose response for MMS appear to be linear to $18.4 \mu \mathrm{g} / \mathrm{ml}$. Single doses of EMS were also moderately toxic $(45-86 \%$ relative total growth) and mutagenic. Dose responses for EMS also appear to be linear, to $712 \mu \mathrm{g} / \mathrm{ml}$ (Fig. 1). A comparison of the actual mixture IMFs with the expected IMFs (determined by adding together the corresponding single agent IMFs; Table 2) resulted in positive $\%$ change values for total mutants: $9,24,59$ and $66 \%$, respective to increasing doses of EMS. Of the two colony types, the \% change values were greater for small-colony mutants: $34,67,117,158 \%$, than large-colony mutants: $-8,-3,26,16 \%$. Total and small-colony mutants were apparently synergized at these levels of EMS. EMS was the variable component in this experiment, and more small-colony mutants were synergized than large-colony mutants. Cloning efficiencies show that cytotoxicity was not synergized.

Figs. 1a-c show the mean values, when the experiment described in Tables 1 and 2 was repeated 5 times. Fig. 1a is a plot of IMFs for total mutants against exposures to EMS, and shows that all mixtures appear to be synergistic. The mean values of $\%$ change were $12,20,35$ and $72 \%$, respectively, with increasing doses of EMS. Fig. $1 \mathrm{~b}$ is a plot of IMFs for small-colony mutants against exposures, and shows higher levels of apparent synergism for all the mixtures. The mean values of $\%$ change were $31,54,73$ and $123 \%$ respectively. Fig. 1c is a plot of IMFs for largecolony mutants against exposures, and shows apparent synergism for the two highest concentrations of EMS only. The mean values of $\%$ change were $-7,-6,11$ and $39 \%$, respectively.

Regression analysis of \% change against EMS concentration was used to test the hypothesis of additivity, and to test the dependency of synergism on EMS concentration. Plots of \% change 
TABLE 1

COLONY COUNTS IN A TYPICAL MIXED EXPOSURE EXPERIMENT WITH A CONSTANT LEVEL OF MMS AND GRADED LEVELS OF EMS

\begin{tabular}{|c|c|c|c|c|c|c|c|c|c|c|}
\hline \multicolumn{2}{|c|}{$(\mu \mathrm{g} / \mathrm{ml})$} & \multirow{2}{*}{$\begin{array}{l}\mathrm{VC} \\
\text { colonies a }\end{array}$} & \multirow{2}{*}{$\mathrm{CE}^{\mathrm{b}}$} & \multirow{2}{*}{$\begin{array}{l}\text { \% Relative } \\
\text { total } \\
\text { growth }^{\mathrm{c}}\end{array}$} & \multicolumn{2}{|l|}{ Total } & \multicolumn{2}{|c|}{ Small-colony } & \multicolumn{2}{|c|}{ Large-colony } \\
\hline EMS & MMS & & & & mutants ${ }^{d}$ & $\mathrm{MF}^{\mathrm{e}}$ & mutants & MF & mutants & MF \\
\hline- & - & 492 & 82 & 100 & 68 & 55 & 5 & 4 & 62 & 50 \\
\hline- & 6.45 & 363 & 60 & 83 & 434 & 479 & 200 & 220 & 234 & 259 \\
\hline 261 & - & 360 & 60 & 86 & 454 & 505 & 132 & 146 & 322 & 358 \\
\hline 392 & - & 342 & 57 & 76 & 677 & 792 & 195 & 228 & 482 & 564 \\
\hline 560 & - & 311 & 52 & 61 & 889 & 1144 & 255 & 327 & 634 & 815 \\
\hline 712 & - & 252 & 42 & 45 & 989 & 1570 & 296 & 469 & 693 & 1100 \\
\hline 261 & 6.45 & 293 & 49 & 67 & 740 & 1011 & 355 & 484 & 385 & 525 \\
\hline 392 & 6.45 & 238 & 40 & 43 & 888 & 1493 & 440 & 739 & 448 & 753 \\
\hline 560 & 6.45 & 150 & 25 & 23 & 921 & 2456 & 441 & 1176 & 480 & 1280 \\
\hline 712 & 6.45 & 102 & 17 & 10 & 833 & 3267 & 449 & 1760 & 384 & 1506 \\
\hline
\end{tabular}

a Viable count (VC), number of colonies formed from 600 cells plated in non-selective medium.

b Cloning efficiency (CE), VC/600.

c \% Relative total growth, (relative 2-day suspension growth) $\times$ (relative cloning efficiency).

d Total mutants, number of mutant colonies formed from $1.5 \times 10^{6}$ cells plated in selective medium.

e Mutant frequency (MF), number of mutant colonies $/ 10^{6}$ survivors.

vs. EMS concentrations are presented in Figs. 2a-c for total mutants, small-colony mutants, and large-colony mutants, respectively. Since levels of MMS (4.30, 6.45 and $8.60 \mu \mathrm{g} / \mathrm{ml}$ ) had no apparent effect on synergism (see analysis below), results from experiments with these MMS levels were pooled in the regression analyses.

These plots of \% change vs. EMS concentration suggest that \% change of total, small, and large colony mutants increased approximately linearly with EMS concentration. We therefore fit the simple linear regression model $E(Y)=a+b x$ (where
$E(Y)$ represents the expected $\%$ change and $x$ the EMS level) using weights as described in the Materials and Methods section. The resulting regression equations were:

$\hat{Y}=-12.9+0.0977 x \quad$ (total mutants)

$\hat{Y}=1.4+0.1315 x \quad$ (small-colony mutants)

$\hat{Y}=-24.1+0.0766 x \quad$ (large-colony mutants)

where $\hat{Y}$ represents the predicted \% change.

The corresponding $F$ statistics for significant regressions of \% change on EMS concentration were: $25.1(\mathrm{df}=1$ and $35, p<0.00002$, total

TABLE 2

SYNERGISM OF MUTANT COLONIES IN A TYPICAL MIXED EXPOSURE EXPERIMENT WITH A CONSTANT LEVEL OF MMS AND GRADED LEVELS OF EMS

\begin{tabular}{|c|c|c|c|c|c|c|c|c|c|c|}
\hline \multicolumn{2}{|c|}{$(\mu \mathrm{g} / \mathrm{ml})$} & \multicolumn{3}{|c|}{ Total mutants } & \multicolumn{3}{|c|}{ Small-colony mutants } & \multicolumn{3}{|c|}{ Large-colony mutants } \\
\hline EMS & MMS & $\begin{array}{l}\text { Actual } \\
\text { IMF }^{\text {a }}\end{array}$ & $\begin{array}{l}\text { Expected } \\
\text { IMF }^{b}\end{array}$ & $\begin{array}{l}\% \\
\text { change }\end{array}$ & $\begin{array}{l}\text { Actual } \\
\text { IMF }\end{array}$ & $\begin{array}{l}\text { Expected } \\
\text { IMF }\end{array}$ & $\begin{array}{l}\% \\
\text { change }\end{array}$ & $\begin{array}{l}\text { Actual } \\
\text { IMF }\end{array}$ & $\begin{array}{l}\text { Expected } \\
\text { IMF }\end{array}$ & $\begin{array}{l}\% \\
\text { change }\end{array}$ \\
\hline 261 & 6.45 & 956 & 874 & 9 & 480 & 358 & 34 & 475 & 517 & -8 \\
\hline 392 & 6.45 & 1438 & 1161 & 24 & 735 & 440 & 67 & 703 & 723 & -3 \\
\hline 560 & 6.45 & 2401 & 1513 & 59 & 1172 & 539 & 117 & 1230 & 974 & 26 \\
\hline 712 & 6.45 & 3212 & 1939 & 66 & 1756 & 681 & 158 & 1456 & 1259 & 16 \\
\hline
\end{tabular}

a Induced mutant frequency (IMF), number of induced mutants per $10^{6}$ survivors.

b Expected IMF based on adding together the single agent IMFs.

c $\%$ change $=\frac{I M F_{A+B}-\left(I M F_{A}+I M F_{B}\right)}{I M F_{A}+I M F_{B}} \times 100$ 


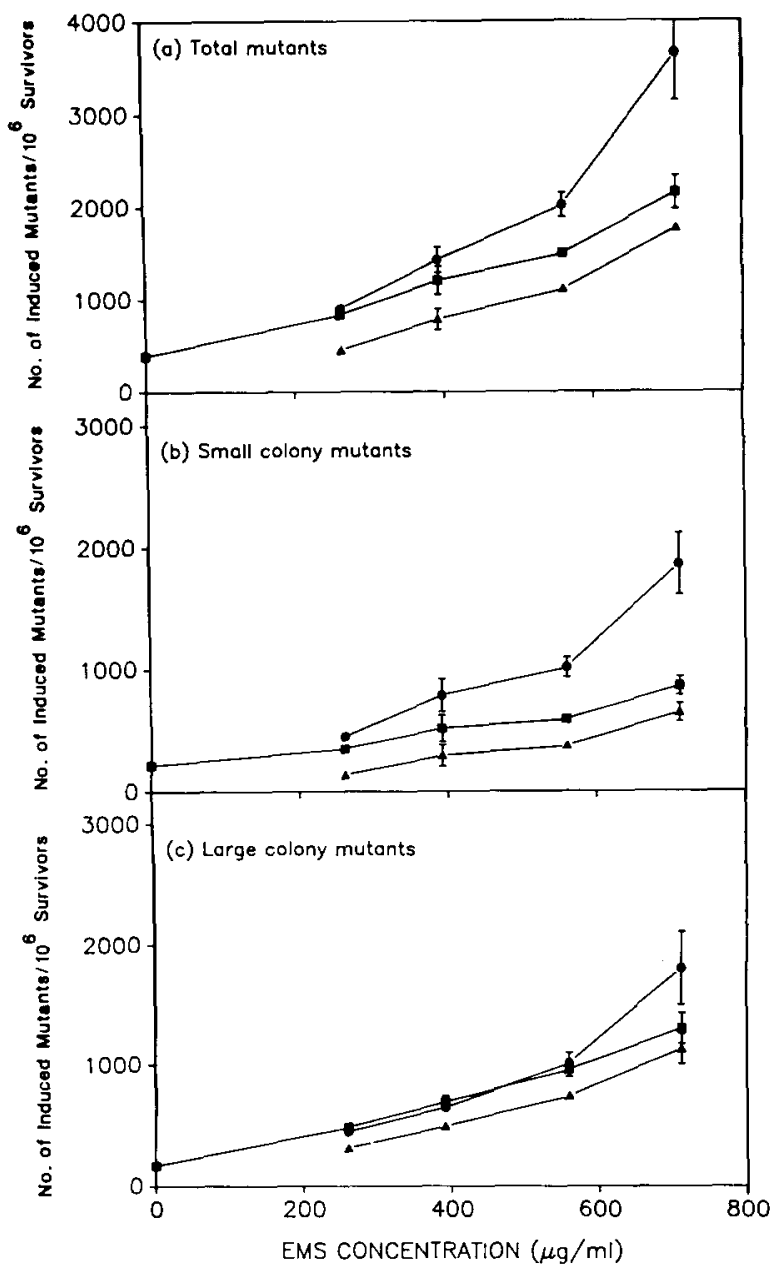

Fig. 1. (a) Synergism in total mutants. (b) Synergism in smallcolony mutants. (c) Synergism in large-colony mutants. (•) Mixed exposures to MMS and EMS; ( $\mathbf{\square})$ arithmetically summed separate EMS and MMS exposures; (ム) single agent exposures to EMS. The point at which the summed single agent exposure curve intersects 0 on the $\mathrm{X}$-axis represents the IMF of 6.45 $\mu \mathrm{g} / \mathrm{ml}$ MMS. The error bars are \pm 1 standard error from the mean in 5 independent Expts., except for the points at 392 $\mu \mathrm{g} / \mathrm{ml}$ EMS for which there are only 3 replicate trials. Error bars were omitted when the standard error was too small to permit an accurate display.

mutants), 21.4 ( $\mathrm{df}=1$ and $35, p<0.0001$, smallcolony mutants), and 19.4 ( $\mathrm{df}=1$ and $35, p<$ 0.0001 , large-colony mutants). Based on this linear model, the estimate curves in each of the plots (the solid lines) represent estimated mean \% change values. The increase in \% change was greatest for small-colony mutants.

We calculated $95 \%$ confidence bands (the dashed lines) for the regression curves. These bands were chosen to have a $95 \%$ prior probability of covering the entire regression curve. They are also plotted in Figs. 2a-c.

The estimate curves suggest that synergism occurs for total and small-colony mutants at all EMS doses tested, and for large-colony mutants at EMS doses above $315 \mu \mathrm{g} / \mathrm{ml}$. The lower 95\% confidence band provides strong evidence of synergism for total and small-colony mutants at all

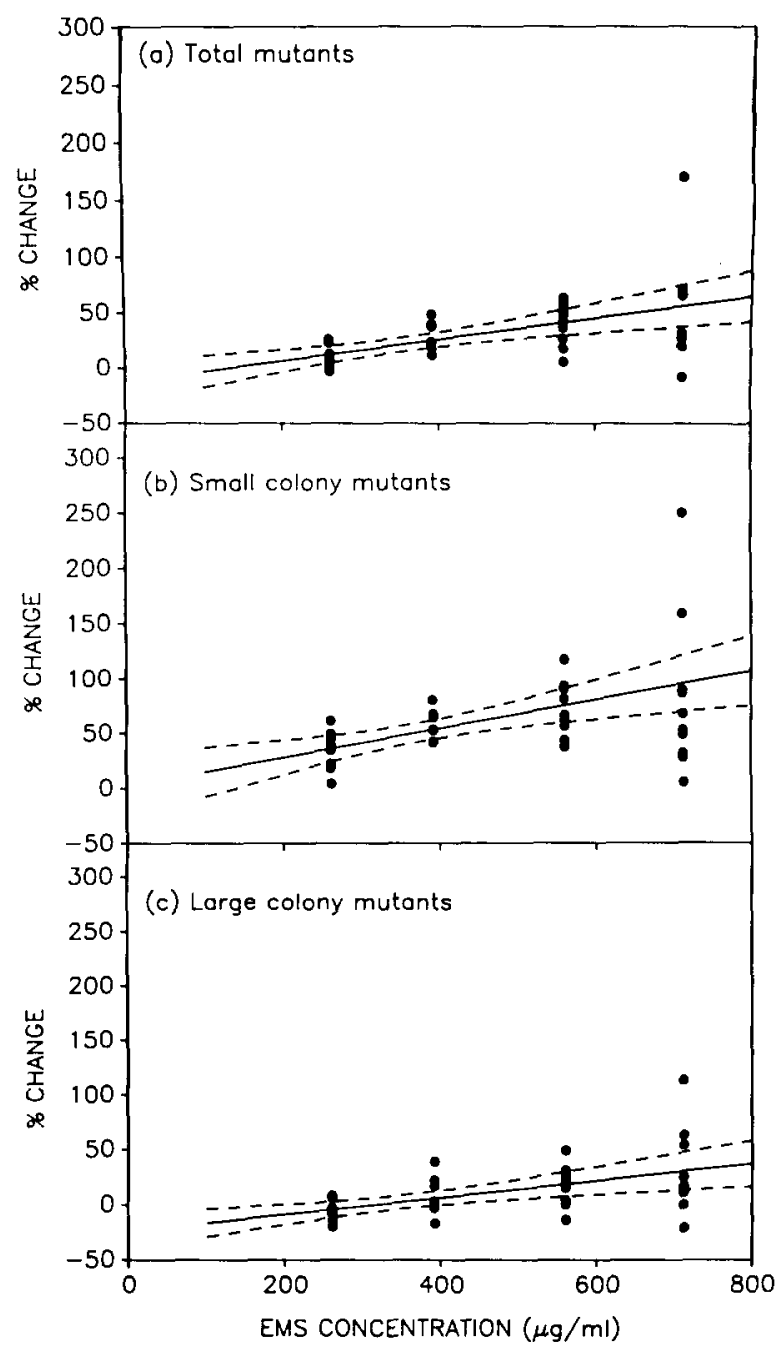

Fig. 2. (a) Estimate curve (solid line) for total colony mutants. (b) Estimate curve (solid line) for small-colony mutants. (c) Estimate curve (solid line) for large-colony mutants. Solid circles represent the $\%$ change value obtained in each experiment. Each Figure shows the 95\% confidence bands (broken lines) for the estimate curve. These estimates were obtained from 10 independent Expts. 
EMS doses tested, and for large-colony mutants above $400 \mu \mathrm{g} / \mathrm{ml}$.

We tested the dependency of synergism on MMS concentration by substituting other constant doses (4.30 and $8.60 \mu \mathrm{g} / \mathrm{ml} \mathrm{MMS}$ ) into mixtures containing the same graded levels of EMS $(261,392,560$ and $712 \mu \mathrm{g} / \mathrm{ml})$. When the \% change values were compared for the 3 MMS levels $(4.30,6.45$ and $8.60 \mu \mathrm{g} / \mathrm{ml})$ by analysis of variance, no significant differences were obtained for total $(F=0.91, \mathrm{df}=2$ and $34, p>0.40)$, small $(F=0.52$, df $=2$ and $34, p>0.60)$, or large-colony mutants $(F=1.17, \mathrm{df}=2$ and $34, p>0.30)$. In this analysis of constant MMS:graded EMS experiments, 3 replicate experiments contained $4.30 \mu \mathrm{g} / \mathrm{ml}$ MMS, 5 replicate experiments contained $6.45 \mu \mathrm{g} / \mathrm{ml} \mathrm{MMS}$, and 2 replicate experiments contained $8.60 \mu \mathrm{g} / \mathrm{ml}$ MMS. Synergism was dependent on EMS concentration but not on MMS concentration.

\section{Discussion}

This paper is part of a systematic study of mixed exposures to mutagens. The identification of a mixture that significantly synergizes mutants in a standard mammalian cell assay points to the need for more information on the incidence, mechanism, and properties of synergism and on the risks that mixed exposures pose for health.

We have established the phenomenon of synergism by showing that mutant frequencies of mixed exposures are greater than the mutant frequencies expected by adding together the corresponding single agent exposures, i.e. $\mathrm{IMF}_{\mathrm{A}+\mathrm{B}}>$ $\mathrm{IMF}_{\mathrm{A}}+\mathrm{IMF}_{\mathrm{B}}$. Testing this simple comparison is permissable because our single agent dose responses follow linear functions (United Nations Scientific Committee, 1982). Fig. 1 shows that the dose response of EMS is linear, within the range that was tested, and our MMS dose response, agreeing with the data of Moore et al. (1985a), also fits a linear function. Even though the absolute number of mutant colonies was not synergized, our data, when corrected for cytotoxicity, show that the induced mutant frequencies were synergized.

One advantage of using the mouse lymphoma cell assay for studying mutagenesis is that these cells produce two types of $\mathrm{TK}^{-/-}$mutants. One type forms large colonies, reflecting single-gene mutations, and the other type forms small colonies, reflecting chromosomal mutations. A good example of the assay's usefulness is the demonstration that simple methyl alkylating agents favor the formation of small-colony mutants, whereas their ethyl analogues favor the formation of large-colony mutants (Clive, 1983; Turner et al., 1984).

These characteristics are exhibited to good advantage in our demonstration of synergism in mixtures that contain a constant dose of MMS and graded doses of EMS. Our analysis shows that the frequency of total mutants is synergized. This frequency is composed of small and large colony mutants. Of the two colony types, smallcolony mutants are synergized to a greater extent and at lower EMS doses than large-colony mutants. Given that EMS favors the formation of large-colony mutants, we expected that if synergism were to occur, increasing the EMS dose would result in increasing synergism of large-colony mutants. Our data shows the opposite effect. Increasing exposures of EMS resulted in increased synergism of small-colony mutants.

We used \% change as a mathematical expression for the magnitude of synergism. Our data show that the \% change values in each experiment were greater than zero for total and small-colony mutants. The significance of the effect was confirmed using a statistical analysis that incorporated all the available data. This analysis suggests that the $\%$ change values, at the doses tested, were significantly greater than zero for total and smallcolony mutants, and greater than zero for largecolony mutants at the highest EMS level tested. The statistical analysis confirms that the variability in the \% change values was low enough to conclude that the mixtures of MMS and EMS were synergistic.

When this assay is conducted properly, the identification of small- and large-colony mutants reflect lesions in the genome rather than extragenetic factors. Competition for nutrients appears not to be a factor, since the number of mutant colonies that we counted in the mixture and single exposure plates were similar. For example, the number of total mutants counted after exposure to $560 \mu \mathrm{g} / \mathrm{ml}$ EMS (Table 1) was 889 colonies. The 
number of total mutants after exposure to 6.45 $\mu \mathrm{g} / \mathrm{ml} \mathrm{MMS}+560 \mu \mathrm{g} / \mathrm{ml}$ EMS was 921 colonies. The similarity in the total number of mutant colonies speaks against the possibility that the increase in small colony mutants in mixed exposures results from "starving" of large-colony mutants by nutrient depletion from other colonies.

Cloning efficiencies (Table 1) show that cytotoxicity was not synergized. The viable count (VC) colonies listed in Table 1, column 3, represent the number of colonies formed from plating 600 cells. For the mixture $(6.45 \mu \mathrm{g} / \mathrm{ml} \mathrm{MMS}+560 \mu \mathrm{g} / \mathrm{ml}$ EMS), the viable count was 150 colonies, implying that the mixture was toxic for 450 cells (i.e., $600-150=450$ ). The viable count for $6.45 \mu \mathrm{g} / \mathrm{ml}$ was 363 ; this exposure was toxic for 237 cells. For $560 \mu \mathrm{g} / \mathrm{ml}$ EMS, the viable count was 311 ; this exposure was toxic for 289 cells. The cytotoxicity of the mixture ( 450 cells) was less than the sum of toxicities for MMS (237 cells) and EMS (289 cells).

We monitored the ratio of small to large mutant colonies in the 5 replicate experiments to assess the variability in colony type from experiment to experiment and to address the concern of an inadvertant counting bias in favor of small-colony mutants in mixed exposure experiments. It is important to show that errors in colony counting are not responsible for the apparent synergism of small colony mutants. Table 3 shows the counts of small and large colony mutants, as well as the ratios in each of the experiments, for $6.45 \mu \mathrm{g} / \mathrm{ml}$ MMS, $560 \mu \mathrm{g} / \mathrm{ml} \mathrm{EMS}$, and $6.45 \mu \mathrm{g} / \mathrm{ml} \mathrm{MMS} \mathrm{+}$ $560 \mu \mathrm{g} / \mathrm{ml}$ EMS. Some variability in the ratios of small to large colonies is evident; however, the ratios for mixtures and single agent exposures within an experiment were always displaced in the same direction (either above or below the mean ratios) in each of the 5 experiments. For example, in Expt. No. 2 (Table 3), the MMS ratio (0.99) was below its mean ratio (1.30), the EMS ratio $(0.44)$ was below its mean $(0.51)$, and the mixture ratio $(0.70)$ was below its mean (1.02). This pattern was consistent for all 5 Expts., except for Expt. No. 4, where the experimental ratios closely approximated the mean ratios. This same pattern was observed in the other single and mixed exposures as well. Since the variabilities in the ratios for mixture and single agent exposures were consistently in the same direction within an experiment, bias in counting appears unlikely.

This paper demonstrates synergism of mutant colonies resulting from exposure of mouse lymphoma cells to binary mixtures of EMS and MMS. Synergism was more apparent in small rather than large colony mutants. These results imply that binary mixtures synergize intergenic (chromosomal) mutations. We have further studies

\section{TABLE 3}

SMALL AND LARGE MUTANT COLONY COUNTS AND THE RATIO OF SMALL TO LARGE MUTANT COLONIES IN 5 INDEPENDENT Expts.

\begin{tabular}{|c|c|c|c|c|c|c|c|c|c|}
\hline \multicolumn{3}{|c|}{$(\mu \mathrm{g} / \mathrm{ml})$} & \multicolumn{5}{|c|}{ Expt. No. } & \multirow[t]{2}{*}{ Mean } & \multirow[t]{2}{*}{$\mathrm{SE}^{\mathrm{b}}$} \\
\hline$\overline{\text { EMS }}$ & MMS & $\overline{\mathrm{CT} / \text { Ratio }^{\mathrm{a}}}$ & $\overline{1}$ & 2 & 3 & 4 & 5 & & \\
\hline- & 6.45 & $S$ & 244 & 131 & 264 & 180 & 200 & 204 & 23.6 \\
\hline- & 6.45 & $\mathbf{L}$ & 171 & 158 & 214 & 175 & 235 & 191 & 14.5 \\
\hline- & 6.45 & $S / L$ & 1.42 & 0.83 & 1.23 & 1.03 & 0.85 & 1.07 & 0.113 \\
\hline 560 & - & $\mathbf{S}$ & 280 & 205 & 321 & 311 & 255 & 274 & 20.9 \\
\hline 560 & - & $\mathbf{L}$ & 551 & 479 & 532 & 599 & 634 & 559 & 26.8 \\
\hline 560 & - & $S / L$ & 0.51 & 0.43 & 0.60 & 0.52 & 0.40 & 0.492 & 0.035 \\
\hline 560 & 6.45 & $\mathbf{S}$ & 484 & 266 & 528 & 444 & 441 & 433 & 44.6 \\
\hline 560 & 6.45 & $\mathrm{~L}$ & 410 & 391 & 455 & 437 & 480 & 435 & 15.8 \\
\hline 560 & 6.45 & $S / L$ & 1.18 & 0.68 & 1.16 & 1.02 & 0.92 & 0.992 & 0.091 \\
\hline
\end{tabular}

a Colony type (CT): small (S), large (L).

b Standard error (SE). 
in progress to more directly demonstrate that binary mixtures do synergize chromosomal mutations.

\section{Acknowledgements}

The authors would like to thank Ms. Susan Modrezejewski for her unrelenting technical efforts.

\section{References}

Amacher, D.E., and S.C. Paillet (1981) Trifluorothymidine resistance and colony size in $\mathrm{L} 5178 \mathrm{Y} / \mathrm{TK}^{+/-}$cells treated with methyl methanesulfonate, J. Cell. Phys., 106, 349-360.

Blazak, W.F., B.E. Stewart, I. Galperin, K.L. Allen, C.J. Rudd, A.D. Mitchell and W.J. Caspary (1986) Chromosome analysis of trifluorothymidine-resistant L5178Y mouse lymphoma cell colonies, Environ. Mutagen., 8, 229-240.

Clive, D. (1983) Viable chromosomal mutations affecting the TK locus in $\mathrm{L} 5178 \mathrm{Y} / \mathrm{TK}^{+/-}$mouse lymphoma cells: The other half of the assay, in: G.M. Williams, V.C. Dunkel and V.A. Ray (Eds.), Cellular Systems for Toxicity Testing, The New York Academy of Sciences, New York, NY, pp. 253-257.

Clive, D., and M.M. Moore-Brown (1979) The L5178Y /TK ${ }^{+/-}$ mutagen assay system: Mutant analysis, in: A. Hsie, J.P. O'Neil and V. McElheny (Eds.), Banbury Report 2: Mammalian Cell Mutagenesis: The Maturation of Test Systems, Cold Spring Harbor Laboratory, NY, pp. 421-429.

Clive, D., K.O. Johnson, J.F.S. Spector, A.G. Batson and M.M.M. Brown (1979) Validation and characterization of the $\mathrm{L} 5178 \mathrm{Y} / \mathrm{TK}^{+/-}$mouse lymphoma mutagen assay system, Mutation Res., 59, 61-108.

Clive, D., A.G. Batson and N.T. Turner (1980) The ability of the $\mathrm{L} 5178 \mathrm{Y} / \mathrm{TK}^{+/-}$mouse lymphoma cells to detect single gene and viable chromosomal mutations: Evaluation and relevance to mutagen and carcinogen screening, in: G.M. Williams, R. Kroes, H.W. Woaijers and K.W. van de Pall (Eds.), The Predictive Value of Short-Term Screening Tests in Carcinogenicity Evaluation, Elsevier, Amsterdam, pp. 103-123.

Harbach, P.R., D.M. Zimmer, R.J. Trzos and B.K. Bhuyan (1982) Synergistic mutagenicity of combinations of two antitumor drugs: 1,3-bis(2-chloroethyl)-1-nitrosourea (BCNU) and streptozocin (SZ), Environ. Mutagen., 4, 321-322.

Hass, B.S., E.E. Brooks, K.E. Schumann and S.S. Dornfeld (1981) Synergistic, additive, and antagonistic mutagenic responses to binary mixtures of benzo[ $a]$ pyrene and benzo[ $e]$ pyrene as detected by strains TA98 and TA100 in the Salmonella/microsome assay, Environ. Mutagen., 3, 159-166.

Hozier, J., J. Sawyer, M. Moore, B. Howard and D. Clive (1981) Cytogenetic analysis of the $\mathrm{L} 5178 \mathrm{Y} / \mathrm{TK}^{+/-}-\mathrm{TK}^{-/ 1}$ mouse lymphoma mutagenesis assay system, Mutation Res., 84, 169-181.

Hozier, J., J. Sawyer, D. Clive and M.M. Moore (1983) Cyto- genetic analysis of small-colony $\mathrm{L} 5178 \mathrm{Y} / \mathrm{TK}^{-/-}$mutants early in their clonal history, in: G.M. Williams, V.C. Dunkel and V.A. Ray (Eds.), Cellular Systems for Toxicity Testing, The New York Academy of Sciences, New York, NY, pp. 423-425.

Hozier, J., J. Sawyer, D. Clive and M.M. Moore (1985) Chromosome 11 aberrations in small colony L5178Y $\mathrm{TK}^{-1-}$ mutants early in their clonal history, Mutation Res., 147, 237-242.

Kozak, C.A., and F.H. Ruddle (1977) Assignment of the genes for thymidine kinase and galactokinase to Mus musculus chromosome 11 and the preferential segregation of this chromosome in Chinese hamster/mouse somatic cell hybrids, Som. Cell Genet., 3, 121-133.

Moore, M.M., D. Clive, B. Howard, A.G. Batson and N.T. Turner (1985a) In situ analysis of trifluorothymidine-resistant (TFTr) mutants of $\mathrm{L} 5178 \mathrm{Y} / \mathrm{TK}^{+/-}$mouse lymphoma cells, Mutation Res., 151, 147-159.

Moore, M.M., D. Clive, J.C. Hozier, B. Howard, A.G. Batson, N.T. Turner and J. Sawyer (1985b) Analysis of trifluorothymidine-resistant (TFTr) mutants of L5178Y $/ \mathrm{TK}^{-1-}$ mouse lymphoma cells, Mutation Res., 151, 161-174.

Moore-Brown, M.M., and D. Clive (1979) The L5178Y /TK ${ }^{+/-}$ mutagen assay system: In situ results, in: A. Hsie, J.P. O’Neil and V. McElheny (Eds.), Banbury Report 2: Mammalian Cell Mutagenesis: The Maturation of Test Systems, Cold Spring Harbor Laboratory, NY, pp. 71-88.

Neter, J., W. Wasserman and M.H. Kutner (1985) Applied Linear Statistical Models, 2nd edn., Richard D. Irwin, Homewood, IL, pp. 154-156, 167-172, 219-220, 244, 263.

Oberly, T.J., B.J. Bewsey and G.S. Probst (1986) Thymidine kinase activity and trifluorothymidine resistance of spontaneous and mutagen-induced L5178Y cells in RPMI 1640 medium, Mutation Res., 161, 165-171.

Rosin, M.P. (1981) The use of bacterial assay to identify which agents modify carcinogen-induced mutagenesis, in: H.F. Stich and R.H.C. San (Eds.), Short-term Tests for Chemical Carcinogens, Springer, New York, p. 449.

Shelef, L.A., and B. Chin (1980) Effect of phenolic antioxidants on the mutagenicity of alfatoxin B1, Appl. Environ. Microbiol., 40, 1039-1043.

Tennant, R.W., D.M. DeMarini and J.W. Spalding (1987) Carcinogenicity and genetic toxicity results on single chemicals: Implications for testing mixtures in: V.B. Vouk, G.C. Butler, A.C. Upton, D.V. Parke and S.C. Asher (Eds.), Methods for Assessing the Effects of Mixtures of Chemicals, Wiley, New York, pp. 759-774.

Turner, N.T., A.G. Batson and D. Clive (1984) Procedures for the $\mathrm{L} 5178 \mathrm{Y} / \mathrm{TK}^{-1-} \rightarrow \mathrm{TK}^{-1-}$ mouse lymphoma cell mutagenicity assay, in: B.J. Kilbey, M. Legator, W. Nichols and C. Ramel (Eds.), Handbook of Mutagenicity Test Procedures, 2nd edn., Elsevier, Amsterdam, pp. 239-268.

United Nations Scientific Committee of the Effects of Atomic Radiation (1982) Ionizing radiation: Sources and Biological Effects, United Nations, New York, pp. 727-773.

Watanabe, M., S. Honda, M. Hayashi and T. Matsuda (1982) Mutagenic effects of chemical carcinogens and environmental pollutants in mice as shown by the micronucleus test, Mutation Res., 97, 43-48. 